\title{
Physiological stress in the smalltooth sawfish: effects of ontogeny, capture method, and habitat quality
}

\author{
Bianca K. Prohaska ${ }^{1, *}$, Dana M. Bethea ${ }^{2}$, Gregg R. Poulakis ${ }^{3}$, Rachel M. Scharer ${ }^{3}$, \\ Ryan Knotek ${ }^{4}$, John K. Carlson ${ }^{5}$, R. Dean Grubbs ${ }^{1}$ \\ ${ }^{1}$ Florida State University Coastal and Marine Laboratory, St. Teresa, Florida 32358, USA \\ ${ }^{2}$ NOAA National Marine Fisheries Service, Southeast Regional Office, Protected Resources Division, St. Petersburg, \\ Florida 33710, USA \\ ${ }^{3}$ Fish and Wildlife Research Institute, Florida Fish and Wildlife Conservation Commission, \\ Charlotte Harbor Field Laboratory, Port Charlotte, Florida 33954, USA \\ ${ }^{4}$ University of Massachusetts Boston, School for the Environment, Boston, Massachusetts 02125, USA \\ ${ }^{5}$ NOAA National Marine Fisheries Service, Southeast Fisheries Science Center, Panama City, Florida 32408, USA
}

\begin{abstract}
Similar to other elasmobranchs, the smalltooth sawfish Pristis pectinata is slow growing, matures late in life, and produces relatively few young, all factors that have contributed to its sensitivity to dramatic population declines from overfishing and habitat loss. Currently, the physiological stress response of these fish to capture or to other physiological challenges such as habitat loss, climatic changes, or pollution is unknown. In the absence of these data, conservation plans may be less effective, making populations susceptible to further declines. We examined basic stress physiology over ontogeny and as a function of capture using different fishing gears. We also examined stress parameters to test whether degraded habitat and water quality from altered habitats may have resulted in chronic stress in juveniles. Results suggested that the stress response to capture by all methods was low, particularly for blood lactate, compared to other elasmobranchs examined to date. Metabolic stress was found to change over ontogeny, with young of the year (YOY) eliciting the highest responses. Glucose, $\mathrm{pCO}_{2}$, bicarbonate, potassium, and hematocrit indicated that gillnet capture induced greater stress responses than longline capture. Significantly higher metabolic stress was observed in YOY and juveniles captured in the 2 nurseries most influenced by anthropogenic activities, the Peace and Caloosahatchee rivers, than in the 2 relatively pristine nurseries in Everglades National Park. Overall, the low physiological stress responses to all capture methods investigated in this study suggest that this species is resilient, which should promote optimism for recovery of the population.
\end{abstract}

KEY WORDS: Pristis pectinata - Stress physiology - Metabolic stress - Chronic stress · Anthropogenic effects $\cdot$ Nursery $\cdot$ Habitat loss $\cdot$ Blood chemistry

\section{INTRODUCTION}

The Pristidae, a small family (5 species) of batoids, is considered the most imperiled of all shark and ray families (Dulvy et al. 2014), and sawfishes are perhaps the most endangered marine fishes in the world (Wueringer et al. 2009, Dulvy et al. 2016). The smalltooth sawfish Pristis pectinata

\footnotetext{
${ }^{*}$ Corresponding author: bprohaska@bio.fsu.edu
}

(Latham 1794) occurs in tropical and subtropical waters within the Atlantic basin (Faria et al. 2013). Pristis pectinata are born at a stretch total length (STL) of approximately $70 \mathrm{~cm}$, and reach maturity at around $340 \mathrm{~cm}$ for males and $380 \mathrm{~cm}$ STL for females, although this species is thought to grow to over $520 \mathrm{~cm}$ STL (Poulakis et al. 2011, R. D. Grubbs \& J. Gelsleichter unpubl. data).

(C) The authors and, outside the USA, the US Government 2018. Open Access under Creative Commons by Attribution Licence. Use, distribution and reproduction are unrestricted. Authors and original publication must be credited. 
Young of the year (YOY) and smaller juvenile $P$. pectinata inhabit shallow estuaries and coastal bays for the first few years of life until reaching around $220 \mathrm{~cm}$ STL (Seitz \& Poulakis 2002, Poulakis \& Seitz 2004, Simpfendorfer et al. 2008, 2010). Adults occupy habitats ranging from shallow coastal estuaries to depths of approximately $100 \mathrm{~m}$ on the continental shelf (Seitz \& Poulakis 2002, Poulakis \& Seitz 2004, Carlson et al. 2014, Waters et al. 2014). The historic range of $P$. pectinata in the United States was from Texas to New York (Poulakis \& Seitz 2004), though the core of the range is southwest Florida. The overall range was reduced dramatically in the last half of the 20th century, and by 2000, reports of sightings outside southwest Florida were uncommon (Seitz \& Poulakis 2002, Poulakis \& Seitz 2004, Wiley \& Simpfendorfer 2010, Waters et al. 2014). Two major nursery regions exist in Florida and were federally designated as Critical Habitat for juveniles: the Charlotte Harbor Estuary Unit and the Ten Thousand Islands National Wildlife Refuge Everglades National Park (TTI/ENP) Unit (Norton et al. 2012). The Charlotte Harbor Estuary Unit is a highly anthropogenically influenced nursery, whereas the TTI/ENP Unit is relatively pristine. In the Charlotte Harbor Estuary Unit, the Caloosahatchee River has been highly altered by the creation of extensive canal systems, and its freshwater flow is regulated through a lock system (Barnes 2005). In contrast, the Peace River is less developed with more natural shorelines, and has unaltered freshwater flow (Poulakis et al. 2011). Within the TTI/ENP Unit, Goodland, Chokoloskee, and Everglades City have some anthropogenic development, and lower Everglades National Park has almost no development (Hollensead et al. 2016).

In the United States, P. pectinata experienced population declines because of bycatch in gillnet and trawl fisheries, direct harvest for the rostra, and habitat loss. Overfishing and habitat loss are believed to be responsible for up to a $95 \%$ decline in the $P$. pectinata population in the United States over the 20th century (Simpfendorfer 2000, Norton et al. 2012). Pristis pectinata were commonly captured in net fisheries in the 19th and 20th centuries, because their toothed rostra easily became entangled in fishing gear (Seitz \& Poulakis 2006). If the fish were still alive when captured, they were likely killed because they were a nuisance species and because their rostrum could be sold in the curio trade (Simpfendorfer 2000, 2005, Wiley \& Simpfendorfer 2007, 2010). Because bycatch was not well recorded in fishery statistics, population declines went unnoticed for many years (Seitz \& Poulakis 2006). Population declines were also likely a result of habitat loss to urban development of mangrove shorelines and adjacent seagrass habitats that $P$. pectinata relied upon (Simpfendorfer 2000, Seitz \& Poulakis 2002, Poulakis \& Seitz 2004, Simpfendorfer 2005, Seitz \& Poulakis 2006, Wiley \& Simpfendorfer 2010). Pristis pectinata are now listed by the IUCN as Critically Endangered, endangered under the US Endangered Species Act (ESA), and under CITES Appendix I, which bans international trade (NMFS 2003, 2009, Carlson et al. 2013).

Despite being listed as endangered, $P$. pectinata are still negatively affected by anthropogenic influences. For example, $P$. pectinata are often encountered by recreational rod and reel fishers that target other species (Poulakis \& Seitz 2004), and in bottom longline fisheries that target sharks (Enzenauer et al. 2016). While gillnet fisheries were eliminated in Florida waters in 1994 (FWC 1999, NMFS 2003), there has been one incident of a $P$. pectinata captured in shark gillnets in federal waters (Carlson \& Baremore 2003), and as the population of P. pectinata begins to recover, there will likely be more interactions with this fishery. Furthermore, P. pectinata are still captured as bycatch in the shrimp trawl fishery, which is likely the largest source of direct fishing mortality (Simpfendorfer 2000, NMFS 2009, Carlson $\&$ Scott-Denton 2011). In addition to continued fisheries interactions, $P$. pectinata are also entangled in marine debris (Seitz \& Poulakis 2006), and mortalities and purposeful injuries, such as rostrum removal, still occur in the United States (Seitz \& Poulakis 2006). Additionally, habitat loss within ESA-designated critical habitat, particularly in the Charlotte Harbor Estuary Unit, continues.

Anthropogenic stressors such as habitat degradation and fisheries interactions can cause acute and chronic stress, which may surpass stress that occurs from natural stressors such as seasonal changes in the environment, capturing prey, and avoiding predators (Skomal \& Bernal 2010). Physiological stress responses are of interest because the physiology of an animal can determine its life history, behavior, and fitness (Ricklefs \& Wikelski 2002, Wikelski \& Cooke 2006). Much of the stress physiology research that has been conducted on teleosts has focused on the primary stress hormone, cortisol, which is readily quantifiable in teleosts; however, the primary stress hormone in elasmobranchs, $1 \alpha$-hydroxycorticosterone, has yet to be validated (Anderson 2012). In fishes, including elasmobranchs, stressors are known to cause a series of other quantifiable physiological changes to the blood chemistry (Skomal \& Bernal 2010). Blood-gases, acid-base status, and blood lac- 
tate are most often used in studies of stress physiology to determine the condition of the fish following a stressor such as capture (Cliff \& Thurman 1984, Wells et al. 1986, Harrenstien et al. 2005, Skomal 2007). These parameters can also be indicators of present or imminent mortality (Hoffmayer \& Parsons 2001, Young et al. 2006, Arlinghaus et al. 2009). Furthermore, in teleosts, the stress response is known to change over ontogeny (Skomal \& Mandelman 2012); however, variation in the stress response over ontogeny has only been investigated in a few species of elasmobranchs, and not over their entire size ranges (Mandelman \& Skomal 2009).

The stress physiology parameters that are typically examined in elasmobranchs include glucose, partial pressure of $\mathrm{CO}_{2}\left(\mathrm{pCO}_{2}\right)$, lactate, bicarbonate, hematocrit, $\mathrm{pH}$, and potassium. Blood glucose is measured as a proxy of the glucocorticoid stress response (Cliff \& Thurman 1984, Hoffmayer \& Parsons 2001, Skomal 2006, Frick et al. 2010a), during which gluconeogenesis occurs and stored hepatic glycogen is mobilized into the blood to serve muscle tissue (Barton \& Iwama 1991, Hoffmayer \& Parsons 2001). Respiratory stress results in elevated blood concentrations of $\mathrm{pCO}_{2}$, and occurs as a result of decreased ventilation, which would otherwise expel excess carbon dioxide. This often occurs for elasmobranchs that are entangled in a gillnet and cannot properly ventilate, or for ramventilating elasmobranchs that have limited mobility when caught on a line (Manire et al. 2001, Mandelman \& Farrington 2007). Increases in blood lactate, termed metabolic acidosis, result from an animal increasing its energetic demands (e.g. when evading predators, pursuing prey, or seeking suitable habitat) (Murdaugh et al. 1965, Rasmussen \& Rasmussen 1967, Piiper \& Baumgarten 1969, Piiper et al. 1972, Martini 1974, Cliff \& Thurman 1984). This causes a switch from aerobic to anaerobic respiration in white muscle tissue, which results in the movement of lactate and $\mathrm{H}^{+}$ions from the muscle to the blood (Black 1958, Schmidt-Nielsen 1997, Skomal 2007). Previous work has identified bicarbonate as having the capacity to potentially buffer $\mathrm{pH}$ alterations caused by lactate (Holeton \& Heisler 1983), indicated by decreasing levels of bicarbonate with increasing metabolic stress. High lactate in muscle tissue may also result in a compensatory mechanism called hemoconcentration (Piiper et al. 1972), which is the movement of fluid from the blood to the muscle to dilute these high concentrations, and can be quantified by observing increases in hematocrit. As a result of increases in $\mathrm{pCO}_{2}$ and lactate, an overall blood acidosis can occur (Cliff \& Thurman 1984, Hoffmayer \& Parsons 2001,
Spargo 2001, Lindinger et al. 2005, Robergs et al. 2004, Mandelman \& Skomal 2009, Brooks et al. 2012). Elevated concentrations of potassium in the blood have been observed in stressed elasmobranchs (Cliff \& Thurman, 1984, Wells et al. 1986, Manire et al. 2001), and occur from intracellular acidosis and the resulting efflux of potassium from muscle cells (Cliff \& Thurman 1984, Moyes et al. 2006). The change in the potassium gradient can alter the excitability of muscle cell membranes (Adams \& Galvan 1986), which has been shown to result in myocardial malfunction in spiny dogfish Squalus acanthias (Martini 1974), and has also been associated with neuromuscular interference (Cliff \& Thurman 1984, Frick et al. 2010a).

Stress physiology can inform researchers of intraspecific or interspecific differences in the response and the major factors contributing to stress (Mandelman \& Skomal 2009, Gallagher et al. 2010). With this knowledge, the stress response can be an indicator of population health (Creel et al. 1997, Wasser et al. 1997). Understanding the physiological response to stress in individual organisms can inform speciesspecific management for conservation (Ferguson \& Tufts 1992, Wikelski \& Cooke 2006, Young et al. 2006), but this has not been studied in any sawfish species. Because data regarding the physiological stress response of the critically endangered $P$. pectinata could be useful to species recovery, we investigated 3 main questions: (1) does the stress response change over ontogeny; (2) does capture method affect the stress response; and (3) does habitat quality affect stress physiology in YOY and juveniles?

\section{MATERIALS AND METHODS}

Smalltooth sawfish Pristis pectinata were sampled from the 3 research surveys that currently exist for the species in the United States, allowing us to sample the broadest geographic area possible, and the full size range of the species. These include the Florida State University (FSU) survey, the National Marine Fisheries Service (NMFS) survey, and the Florida Fish and Wildlife Conservation Commission (FWC) survey.

\section{FSU survey}

The ongoing FSU survey targeted large juvenile and adult $P$. pectinata using fishery-independent longlines consisting of a $4.0 \mathrm{~mm}$ monofilament main- 
line that was anchored on each end and marked with a surface buoy bearing the permit numbers. Each mainline set was approximately $750 \mathrm{~m}$ long. A standard set included 50 gangions consisting of a stainless steel tuna clip with an 8/0 stainless steel swivel attached to $2.5 \mathrm{~m}$ of $300 \mathrm{~kg}$ monofilament that was doubled in the terminal $25 \mathrm{~cm}$ and attached to $16 / 0$ non-offset circle hook. Hooks were baited with ladyfish Elops saurus or Spanish mackerel Scomberomorus maculatus. Depth (m), turbidity $(\mathrm{cm})$, water temperature $\left({ }^{\circ} \mathrm{C}\right)$, salinity, and dissolved oxygen (mg $1^{-1}$ ) were recorded from the surface to the bottom for all sets made in depths of less than $10 \mathrm{~m}$, and bottom water temperature $\left({ }^{\circ} \mathrm{C}\right)$ was recorded for those greater than $10 \mathrm{~m}$ deep. Soak times were $1 \mathrm{~h}$ to minimize mortality, and all lines were set during daylight hours. The line was hauled in the order and direction it was set and $P$. pectinata were sampled as they were caught during retrieval. Areas sampled included the Atlantic side of the Florida Keys from Key West to Islamorada and inside ENP from Florida Bay north to Ponce de Leon Bay.

Opportunistically, YOY and juvenile $P$. pectinata were also captured during this survey using rod and reel as well as a dip net. Hook size for rod and reel ranged from 10/0 to 16/0 circle hooks, and were baited with E. saurus or S. maculatus. Fight time for all rod and reel captures was less than $1 \mathrm{~min}$. The dip-net-captured YOY P. pectinata was visually spotted in the shallows at Eagle Key in Florida Bay. The YOY swam into the large dip net, and was immediately restrained and sampled within $1 \mathrm{~min}$.

\section{NMFS survey}

During NMFS surveys, gillnets were used to capture YOY and juveniles. Gillnets were $1.5 \mathrm{~m}$ deep and either 30.5 or $61.0 \mathrm{~m}$ long with stretched mesh sizes of either 7.6 or $10.2 \mathrm{~cm}$, respectively. Nets had continuous float and lead lines, were anchored at each end with a $3.6 \mathrm{~kg}$ mushroom anchor, and marked with large surface buoys at each end. Depth $(\mathrm{m})$, turbidity $(\mathrm{cm})$, water temperature $\left({ }^{\circ} \mathrm{C}\right)$, salinity, and dissolved oxygen $\left(\mathrm{mg} \mathrm{l}^{-1}\right)$ were recorded at the beginning of each set. All sets were made during daylight hours. One net was fished at a time, monitored continuously, soaked for $1 \mathrm{~h}$, and checked for catch every $0.5 \mathrm{~h}$ or immediately if any animal was observed in the gear. Pristis pectinata were untangled and sampled as soon as possible. Areas surveyed were in southwest Florida from Marco Island to Florida Bay, and were divided into 2 distinct geo- graphic areas for analyses. Upper Everglades (UE) was denoted as the area from Marco Island southeast through the Ten Thousand Island National Wildlife Refuge and northern ENP. Florida Bay and the lower Everglades (FLBLE) was denoted as the area encompassing Whitewater and Coot bays, Flamingo, and Florida Bay.

\section{FWC survey}

Pristis pectinata were captured from the Peace and Caloosahatchee rivers using the methods described by Poulakis et al. (2011). Briefly, P. pectinata were captured in gillnets soaked for $1 \mathrm{~h}$ in areas where $P$. pectinata had recently been reported by the public or sites where they were previously caught. Depth (m), water temperature $\left({ }^{\circ} \mathrm{C}\right)$, salinity, and dissolved oxygen $\left(\mathrm{mg} \mathrm{l}^{-1}\right)$ were recorded at the beginning of each set. Nets were constantly monitored and checked when fishes of any type were seen in them (e.g. when splashing was observed) or every $0.5 \mathrm{~h}$, whichever came first. When water clarity was favorable, $P$. pectinata were actively searched for and gillnets were used to catch any animals seen. After being untangled, captured $P$. pectinata were placed in the net well of the vessel or in tubs filled with ambient water and sampled as soon as possible. Dissolved oxygen concentrations were monitored and water changes occurred as necessary to maintain water quality.

\section{Sampling and sample analyses}

As soon as a $P$. pectinata was removed from the gear, it was restrained and a 1-5 ml blood sample was immediately collected, in $30 \mathrm{~s}$ or less, by caudal venipuncture using a 16-22 gauge needle attached to a heparinized syringe. To assess $\mathrm{pCO}_{2}$, lactate, bicarbonate, and $\mathrm{pH}$, a small aliquot of blood was immediately loaded into a CG4+ cartridge and then inserted into a VetScan i-STAT 1 point of care device (Abaxis), which has been validated for use in elasmobranchs (Mandelman \& Farrington 2007, Mandelman \& Skomal 2009, Gallagher et al. 2010). Glucose was then measured using an Accu-Chek glucose meter (Roche Diagnostics), which has been validated for use in fishes (Cooke et al. 2008). Blood samples were placed on ice in a cooler $\left(4^{\circ} \mathrm{C}\right)$ for up to $12 \mathrm{~h}$.

After blood sampling, all captured $P$. pectinata were measured (STL) and assessed for life stage, and sex was determined (YOY were $<150 \mathrm{~cm}$ STL, juve- 
niles were immature animals $\geq 150 \mathrm{~cm}$ STL, adult males had calcified claspers and were $\geq 340 \mathrm{~cm}$ STL, and adult females were $\geq 380 \mathrm{~cm}$ STL) (Simpfendorfer et al. 2008, R. D. Grubbs \& J. Gelsleichter, unpubl. data). Rostral teeth were counted (left and right, independently). All animals were then externally tagged and released.

Upon returning to land, hematocrit was measured in duplicate by filling a capillary tube with the homogenized blood sample, capping one end with clay, and spinning the tube in a hematocrit centrifuge at $15000 \times g$ for $5 \mathrm{~min}$. Hematocrit was determined by calculating the red blood cell percentage of the whole blood volume. The remaining whole blood was then centrifuged at $1800 \times g$ for $5 \mathrm{~min}$ (Unico). The separated plasma was stored at $-20^{\circ} \mathrm{C}$. Plasma potassium $\left(\mathrm{K}^{+}\right)$concentrations were measured using a Single-Channel Digital Flame Photometer (Model 02655-00, Cole-Parmer). Each sample was prepared using a 1:100 dilution of plasma to Cole-Parmer diluent. Potassium standards $\left(\mathrm{K}^{+}: 0.5,1,2\right.$, and $\left.5 \mathrm{ppm}\right)$ were prepared with a 1000 ppm stock solution. Potassium ions were measured by running a standard curve (in triplicate) before the samples, which were then measured in triplicate and in groups of 5 . This process was repeated to ensure proper calibration. Measurement of each standard and sample dilution followed protocol developed by the manufacturer (Cole-Parmer), wherein the standard or sample was aspirated for $20 \mathrm{~s}$ prior to recording the concentration. Between each measurement, air was aspirated for $10 \mathrm{~s}$, followed by Cole-Palmer diluent for $20 \mathrm{~s}$ and air again for $10 \mathrm{~s}$.

\section{Statistical analyses}

Stress physiology data for $\mathrm{pCO}_{2}$, bicarbonate, and $\mathrm{pH}$ were temperature-corrected to water temperature measurements at the time of capture (Mandelman \& Skomal 2009, Gallagher et al. 2010). Hematocrit data were arcsine transformed prior to analyses.

To investigate physiological differences over ontogeny, one-way ANOVA or Kruskal-Wallis tests, depending on whether data were normally distributed, were conducted between the YOY, juvenile, and adult blood parameters: glucose, $\mathrm{pCO}_{2}$, lactate, bicarbonate, $\mathrm{pH}$, potassium, and hematocrit. For these analyses, $P$. pectinata were assessed by ontogenetic stage only and the capture method was not taken into account. If the results indicated a significant difference, a Tukey post hoc test was conducted to determine significant pairwise differences be- tween ontogenetic stages. When a significant difference was identified between YOY and juvenile life stages, an additional independent $t$-test or Welch's $t$-test, depending on whether data were normally distributed, was conducted only on gillnet captured YOY and juveniles to control for any effects of capture method.

To assess differences in the physiological stress response of $P$. pectinata to different methods of capture, one-way ANOVA or Kruskal-Wallis tests were conducted on the following blood parameters between shallow longline $(<5 \mathrm{~m})$, deep longline $(>50$ $\mathrm{m})$, and gillnet captured individuals, regardless of life stage: glucose, $\mathrm{pCO}_{2}$, lactate, bicarbonate, $\mathrm{pH}$, potassium, and hematocrit. Dip net and rod and reel data were omitted from these analyses because of low sample size. When the results of the ANOVA were significant, a Tukey post hoc test was conducted to determine significant pairwise differences between the different capture methods. If a significant difference was identified between shallow and deep longline captured $P$. pectinata, an additional independent $t$-test or Welch's $t$-test was conducted only on data from adults captured by shallow longline and deep longline to control for any influence of juveniles that were also captured by longline. While juveniles were omitted from these analyses, juveniles and adults captured by shallow longline were analyzed using independent $t$-tests, and no significant differences were noted for any of the parameters.

To investigate the potential effects of habitat quality on YOY and larger juvenile stress physiology, one-way ANOVA or Kruskal-Wallis tests were conducted on glucose, $\mathrm{pCO}_{2}$, lactate, bicarbonate, $\mathrm{pH}$, and hematocrit data of gillnet captured $P$. pectinata comparing FLBLE, UE, the Caloosahatchee River, and the Peace River. If the results were significant, a Tukey post hoc test was conducted to identify significant pairwise differences between nurseries. Because the sample sizes for potassium ion results were smaller than those of the other stress parameters, the more pristine nurseries, FLBLE and UE, were pooled (FBEV), and the more anthropogenically influenced nurseries, Caloosahatchee River and Peace River, were pooled (PC) and a $t$-test was conducted. If a significant difference between YOY and juvenile stages was identified for a particular parameter in the previous ontogenetic analyses, only YOY data were used for this analysis; however, if no significant difference was noted for a particular parameter, then YOY and juvenile data were pooled. 
All statistical analyses were conducted, and figures were made using $\mathrm{R}$ version 3.0.3 ( $\mathrm{R}$ Development Core Team 2014). All tests were considered significant at $\alpha=0.05$.

\section{RESULTS}

In total, blood samples were collected from 83 smalltooth sawfish Pristis pectinata, 42 YOY, 13 juveniles, and 28 adults (Table 1). A total of 22 individuals were captured by shallow longline (5 juveniles, 17 adults), 11 adults by deep longline, 46 by gillnet (39 YOY, 7 juveniles), 3 by rod and reel (2 YOY, 1 juvenile), and 1 YOY by dip net (Table 2). From the YOY and juvenile surveys, 7 were captured in FLBLE, 11 in UE, 9 in the Caloosahatchee River, and 22 in the Peace River (Table 3).

\section{Ontogeny and capture method}

With respect to ontogeny, no significant difference was found in $P$. pectinata blood glucose concentrations (ANOVA: $F_{2,65}=0.37, \mathrm{p}=0.696$ ). Blood glucose was significantly higher in $P$. pectinata captured in gillnets than in those captured by shallow longlines, although there were no significant differences between those captured in gillnets and deep longlines, or between those captured by deep longline and shallow longline (ANOVA: $F_{2,60}=6.02, \mathrm{p}=0.004$; Fig. 1A). However, adults captured by deep longlines had significantly higher blood glucose than those caught by shallow longlines ( $t$-test: $t=3.78, \mathrm{df}=12$, $\mathrm{p}=0.003$ ). Though not included in the analysis, the YOY $P$. pectinata captured by dip net had 2- to 3-fold higher blood glucose levels than YOY caught using the other capture methods.

Table 1. Concentrations of stress physiology parameters (mean \pm SE) in smalltooth sawfish Pristis pectinata young of the year

(YOY), juveniles, and adults. Sample sizes in parentheses

\begin{tabular}{|lccccccc|}
\hline & $\begin{array}{c}\text { Glucose } \\
\left(\mathrm{mmol} \mathrm{l}^{-1}\right)\end{array}$ & $\begin{array}{c}\mathrm{pCO}_{2} \\
(\text { torr })\end{array}$ & $\begin{array}{c}\text { Lactate } \\
\left(\mathrm{mmol} \mathrm{l}^{-1}\right)\end{array}$ & $\begin{array}{c}\text { Bicarbonate } \\
\left(\mathrm{mmol} \mathrm{l}^{-1}\right)\end{array}$ & $\mathrm{pH}$ & $\begin{array}{c}\text { Potassium } \\
\left(\mathrm{mmol} \mathrm{l}^{-1}\right)\end{array}$ & $\begin{array}{c}\text { Hematocrit } \\
(\%)\end{array}$ \\
\hline YOY & $2.30 \pm 0.14(42)$ & $10.13 \pm 0.38(37)$ & $3.56 \pm 0.46(37)$ & $7.05 \pm 0.33(37)$ & $7.17 \pm 0.02(37)$ & $12.58 \pm 1.29(12)$ & $27.81 \pm 0.83(42)$ \\
Juvenile & $2.31 \pm 0.36(11)$ & $7.97 \pm 0.83(11)$ & $2.00 \pm 0.38(11)$ & $6.63 \pm 0.63(11)$ & $7.25 \pm 0.02(11)$ & $7.70 \pm 1.26(8)$ & $22.54 \pm 0.95(13)$ \\
Adult & $2.04 \pm 0.36(15)$ & $5.52 \pm 0.50(24)$ & $2.38 \pm 0.14(21)$ & $4.58 \pm 0.39(24)$ & $7.24 \pm 0.01(24)$ & $6.64 \pm 0.76(16)$ & $23.27 \pm 0.81(26)$ \\
\hline
\end{tabular}

Table 2. Concentrations of stress physiology parameters (mean \pm SE) in smalltooth sawfish Pristis pectinata captured by shallow longline (SLL), deep longline (DLL), gillnet (GN), rod and reel (RR), and dip net (DN). Sample sizes in parentheses

\begin{tabular}{|cccccccc|}
\hline & $\begin{array}{c}\text { Glucose } \\
\left(\mathrm{mmol} \mathrm{l}^{-1}\right)\end{array}$ & $\begin{array}{c}\mathrm{pCO}_{2} \\
(\mathrm{torr})\end{array}$ & $\begin{array}{c}\text { Lactate } \\
\left(\mathrm{mmol} \mathrm{l}^{-1}\right)\end{array}$ & $\begin{array}{c}\text { Bicarbonate } \\
\left(\mathrm{mmol} \mathrm{l}^{-1}\right)\end{array}$ & $\mathrm{pH}$ & $\begin{array}{c}\text { Potassium } \\
\left(\mathrm{mmol}^{-1}\right)\end{array}$ \\
\hline $\mathrm{SLL}$ & $1.63 \pm 0.14(13)$ & $5.43 \pm 0.52(17)$ & $2.54 \pm 0.28(16)$ & $4.18 \pm 0.31(17)$ & $7.22 \pm 0.02(17)$ & $6.41 \pm 0.55(11)$ & $23.13 \pm 0.67(21)$ \\
DLL & $3.12 \pm 0.90(5)$ & $6.10 \pm 0.33(9)$ & $2.53 \pm 0.26(7)$ & $4.82 \pm 0.52(9)$ & $7.22 \pm 0.04(7)$ & $6.72 \pm 1.40(8)$ & $23.50 \pm 1.76(10)$ \\
GN & $2.16 \pm 0.07(46)$ & $10.01 \pm 0.38(41)$ & $3.40 \pm 0.43(41)$ & $6.96 \pm 0.28(41)$ & $7.17 \pm 0.02(41)$ & $12.26 \pm 1.11(15)$ & $27.44 \pm 0.78(46)$ \\
RR & $2.98 \pm 1.12(3)$ & $9.80 \pm 0.43(3)$ & $1.16 \pm 0.68(3)$ & $8.76 \pm 1.75(3)$ & $7.26 \pm 0.08(3)$ & $4.58(1)$ & $23.08 \pm 2.81(3)$ \\
DN & $7,44(1)$ & $10.80(1)$ & $0.93(1)$ & $9.67(1)$ & $7.40(1)$ & $5.84(1)$ & $17.75(1)$ \\
\hline
\end{tabular}

Table 3. Concentrations of stress physiology parameters (mean \pm SE) in smalltooth sawfish Pristis pectinata young of the year and juveniles captured in Florida Bay/lower Everglades (FLBLE), upper Everglades (UE), the Caloosahatchee River (CAL), and the Peace River (Peace).

Sample sizes in parentheses

\begin{tabular}{|c|c|c|c|c|c|c|c|}
\hline & $\begin{array}{l}\text { Glucose } \\
\left(\mathrm{mmol} \mathrm{l}^{-1}\right)\end{array}$ & $\begin{array}{l}\mathrm{pCO}_{2} \\
\text { (torr) }\end{array}$ & $\begin{array}{l}\text { Lactate } \\
\left(\mathrm{mmol} \mathrm{l}^{-1}\right)\end{array}$ & $\begin{array}{l}\text { Bicarbonate } \\
\left(\mathrm{mmol} \mathrm{l}^{-1}\right)\end{array}$ & $\mathrm{pH}$ & $\begin{array}{l}\text { Potassium } \\
\left(\mathrm{mmol} \mathrm{l}^{-1}\right)\end{array}$ & $\begin{array}{c}\text { Hematocrit } \\
(\%)\end{array}$ \\
\hline FLBLE & $2.87 \pm 0.81$ & $8.00 \pm 0.51$ & $0.97 \pm 0.25$ & $7.72 \pm 0.74$ & $7.30 \pm 0.03$ & $10.75 \pm 1.54(7)^{\mathrm{a}}$ & $20.89 \pm 1.36$ \\
\hline UE & $1.97 \pm 0.17$ & $9.94 \pm 0.66$ & $1.11 \pm 0.35$ & $8.55 \pm 0.62$ & $7.26 \pm 0.03$ & & $24.23 \pm 1.45$ \\
\hline CAL & $1.90 \pm 0.09$ & $10.76 \pm 0.89$ & $2.30 \pm 0.58$ & $7.58 \pm 0.61$ & $7.18 \pm 0.03$ & $13.58 \pm 1.51(8)^{\mathrm{a}}$ & $28.11 \pm 1.30$ \\
\hline Peace & $2.35 \pm 0.08$ & $10.33 \pm 0.54$ & $5.09 \pm 0.58$ & $6.32 \pm 0.37$ & $7.12 \pm 0.03$ & & $30.26 \pm 0.87$ \\
\hline
\end{tabular}



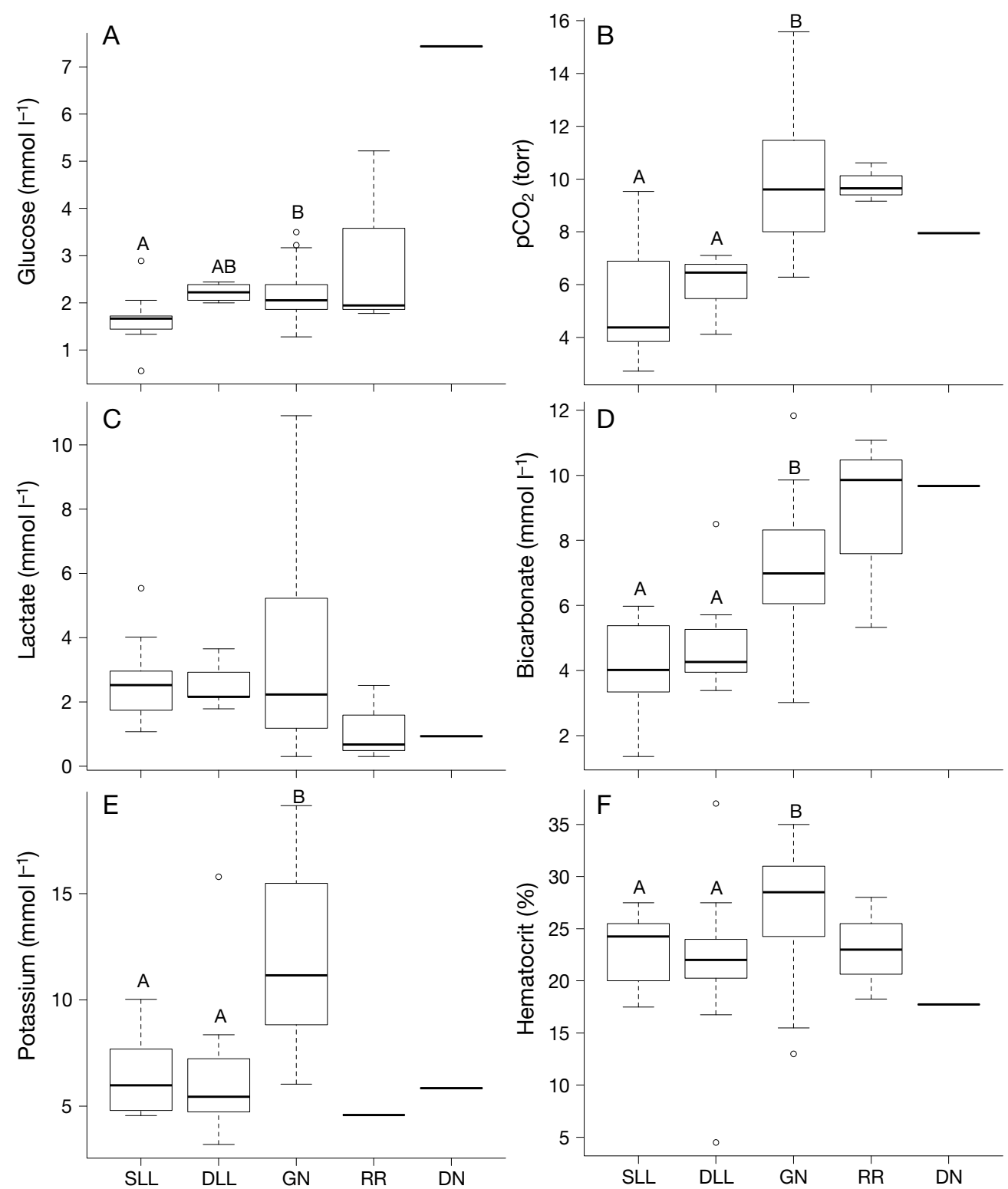

Fig. 1. Boxplots of (A) glucose concentration ( $\mathrm{mmol} \mathrm{l}^{-1}$ ), (B) $\mathrm{pCO}_{2}$ (torr), (C) lactate concentration (mmol $\mathrm{l}^{-1}$ ), (D) bicarbonate concentration $\left(\mathrm{mmol} \mathrm{l}^{-1}\right),(\mathrm{E})$ potassium concentration $\left(\mathrm{mmol} \mathrm{l}^{-1}\right)$, and $(\mathrm{F})$ hematocrit $(\%)$ in smalltooth sawfish Pristis pectinata captured via 5 different methods: shallow longline (SLL), deep longline (DLL), gillnet (GN), rod and reel (RR), and dip net (DN). Different letters indicate significant pairwise differences. RR and DN were not included in any statistical analyses. The top and bottom of the boxes indicate the 75 and $25 \%$ quartiles, respectively, the bold lines are the medians, the upper and lower whiskers indicate the maximum and minimum values within 1.5 times the inter-quartile range, and the points outside of the whiskers indicate outliers

Blood $\mathrm{pCO}_{2}$ concentrations were significantly higher in YOY than in juveniles and adults, and concentrations of $\mathrm{pCO}_{2}$ were significantly higher in juveniles than in adults (ANOVA: $F_{2,69}=25.91, \mathrm{p}<0.001$; Fig. 2A). There was no significant difference in $\mathrm{pCO}_{2}$ concentrations between gillnet captured YOY and juveniles ( $t$-test: $t=-1.14, \mathrm{df}=40, \mathrm{p}=0.263)$. Gillnet captured P. pectinata had significantly elevated $\mathrm{pCO}_{2}$ compared to both shallow and deep longline captured individuals (ANOVA: $F_{2,64}=31.67, \mathrm{p}<0.001 ;$ Fig. $1 \mathrm{~B}$ ). While not included in the ANOVA, rod and reel captured $P$. pectinata also had elevated $\mathrm{pCO}_{2}$ levels, comparable to those of gillnet captured individuals.

There was a significant difference in lactate over ontogeny; however, no significant pairwise differences between life stages were found (ANOVA: $F_{2,66}$ $=3.14, p=0.0497$; Fig. 2B). In gillnet captured YOY and juveniles, YOY lactate levels were significantly 

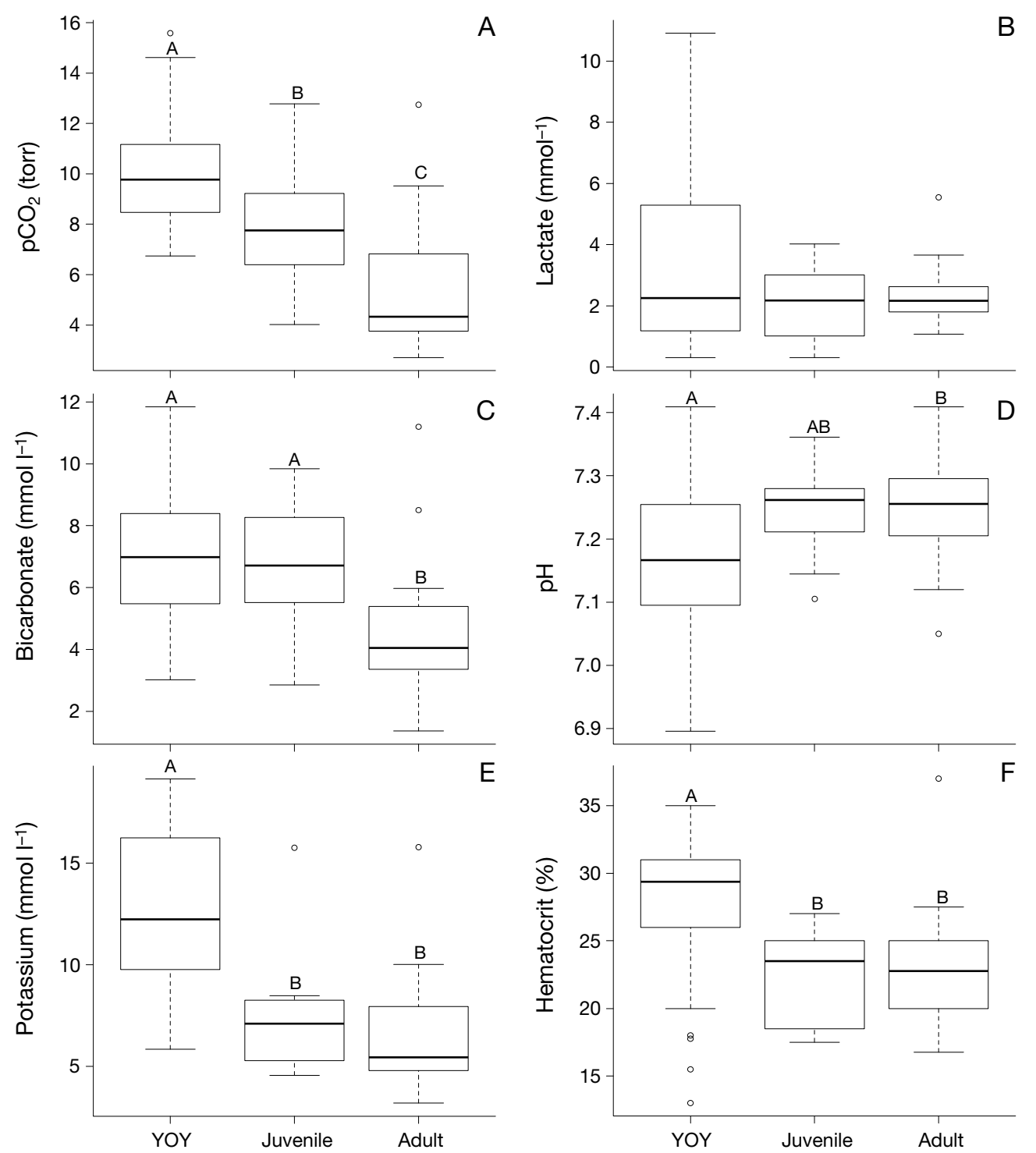

Fig. 2. Boxplots of $(\mathrm{A}) \mathrm{pCO}_{2}$ (torr), (B) lactate concentration $\left(\mathrm{mmol} \mathrm{l}^{-1}\right)$, (C) bicarbonate concentration (mmol $\left.\mathrm{l}^{-1}\right)$, (D) $\mathrm{pH},(\mathrm{E})$ potassium concentration $\left(\mathrm{mmol} \mathrm{l}^{-1}\right)$, and $(\mathrm{F})$ hematocrit $(\%)$ in the 3 smalltooth sawfish Pristis pectinata ontogenetic stages: young of the year (YOY), juvenile, and adult. Different letters indicate significant pairwise differences. For an explanation of the box plots see Fig. 1

higher than those of juveniles (Welch's $t$-test: $t=$ $-4.00, \mathrm{df}=28.19 ; \mathrm{p}<0.001)$. No significant differences in lactate were found between shallow longline, deep longline, and gillnet captured $P$. pectinata (ANOVA: $F_{2,61}=0.86, \mathrm{p}=0.427$ ). While not statistically compared, rod and reel and dip net captured $P$. pectinata displayed lactate levels about half those of shallow longline, deep longline, and gillnet captured individuals (Fig. 1C).

YOY and juvenile $P$. pectinata blood contained significantly higher concentrations of bicarbonate than adults (ANOVA: $F_{2,69}=11.14, \mathrm{p}<0.001$; Fig. $2 \mathrm{C}$ ). Bicarbonate was significantly depressed in P. pecti- nata captured by shallow and deep longlines compared with that of those captured in gillnets (ANOVA: $F_{2,64}=20.21, \mathrm{p}<0.001$; Fig. 1D). While not statistically compared, rod and reel and dip net captured P. pectinata had higher concentrations of bicarbonate, similar to those of gillnet captures.

Blood $\mathrm{pH}$ of YOY was significantly lower than that of adults; however, no significant difference in blood $\mathrm{pH}$ was identified between YOY and juveniles or juveniles and adults (ANOVA: $F_{2,69}=4.66, \mathrm{p}=0.013$; Fig. 2D). When analyzed separately, YOY blood $\mathrm{pH}$ was significantly lower than juveniles for $P$. pectinata captured in gillnets only ( $t$-test: $t=2.41, \mathrm{df}=40, \mathrm{p}=$ 
0.021). No significant differences were found in $P$. pectinata blood $\mathrm{pH}$ between the 3 capture methods (ANOVA: $F_{2,64}=1.30, \mathrm{p}=0.279$ ). While not statistically compared, the $1 P$. pectinata captured by dip net had a pH that was higher than that of the mean $\mathrm{pH}$ of other capture methods (Table 2).

Concentrations of potassium in the plasma were significantly higher in YOY than in juvenile and adult $P$. pectinata (ANOVA: $F_{2,33}=9.43$, p <0.001; Fig. $2 \mathrm{E}$ ). When analyzing gillnet captured YOY and juveniles, no significant difference was found in plasma potassium ( $t$-test: $t=1.44$, $\mathrm{df}=13, \mathrm{p}=0.173$ ). Plasma potassium was significantly higher in $P$. pectinata captured in gillnets compared to individuals captured by both shallow and deep longlines (ANOVA: $F_{2,31}=10.64$, p < 0.001; Fig. 1E). While not statistically compared, the concentrations of plasma potassium in the rod and reel and dip net captured $P$. pectinata were lower compared to individuals caught using the other methods.

A significantly higher percent hematocrit was observed in YOY compared with juveniles and adults (ANOVA: $F_{2,78}=10.45, \mathrm{p}<0.001$; Fig. $2 \mathrm{~F}$ ). When comparing only gillnet captured YOY and juveniles, YOY percent hematocrit was still observed to be significantly higher than that of juveniles ( $t$-test: $t=-3.41$, $\mathrm{df}=45, \mathrm{p}=0.001)$. A significant hemoconcentration was observed in $P$. pectinata captured in gillnets compared to those caught by shallow and deep longlines (ANOVA: $F_{2,75}=7.92, \mathrm{p}<0.001$; Fig. $1 \mathrm{~F}$ ). While not statistically compared, rod and reel and dip net captured $P$. pectinata percent hematocrit was lower than that of those captured in gillnets, and more comparable to that of those captured by shallow and deep longlines (Fig. 1F).

\section{Habitat quality}

No significant difference in YOY or juvenile $P$. pectinata blood glucose or $\mathrm{pCO}_{2}$ was observed between the 4 nurseries sampled (glucose ANOVA: $F_{3,45}$ $=2.13, \mathrm{p}=0.11 ; \mathrm{pCO}_{2}$ ANOVA: $\left.F_{3,40}=2.31, \mathrm{p}=0.091\right)$.

Significantly elevated blood lactate was identified in YOY $P$. pectinata sampled from the Peace River when compared to the other nurseries (ANOVA: $F_{3,33}=8.19, \mathrm{p}<0.001$; Fig. 3A). While not significant,
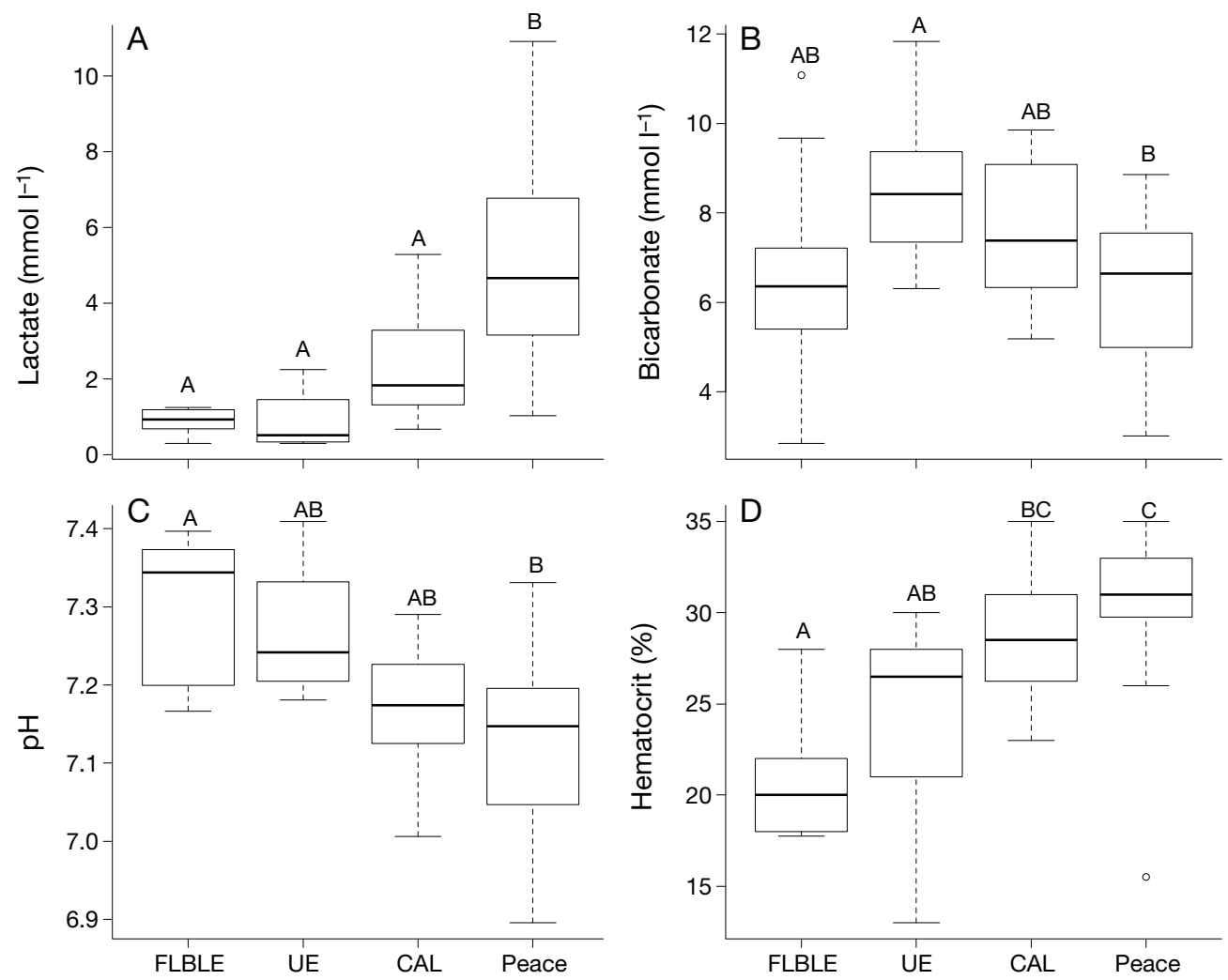

Fig. 3. Boxplots of (A) lactate concentration $\left(\mathrm{mmol} \mathrm{l}^{-1}\right)$, (B) bicarbonate concentration $\left(\mathrm{mmol} \mathrm{l}^{-1}\right)$, (C) $\mathrm{pH}$, and (D) hematocrit (\%) in young of the year smalltooth sawfish Pristis pectinata captured in the more pristine Florida Bay and lower Everglades (FLBLE) and upper Everglades (UE), and in the anthropogenically influenced Caloosahatchee River (CAL), and the Peace River (Peace). Plot B includes juveniles. Different letters indicate significant pairwise differences. For an explanation of the box plots see Fig. 1 
the median blood lactate concentration in YOY from the Caloosahatchee River was nearly double that from the FLBLE and UE nurseries.

YOY and juveniles in the UE had significantly higher bicarbonate than those from the Peace River (ANOVA: $F_{3,40}=3.63, \mathrm{p}=0.021$; Fig. 3B). When solely investigating YOY, there was no significant difference in blood bicarbonate between the 4 nurseries (ANOVA: $F_{3,33}=2.86, \mathrm{p}=0.052$ ).

YOY blood pH was significantly lower in the Peace River than in the FLBLE, although it was not significantly lower than that of UE or the Caloosahatchee River (ANOVA: $F_{3,33}=4.57, \mathrm{p}=0.009$; Fig. 3C).

No significant difference in YOY and juvenile plasma potassium was identified when results from FLBLE and UE were pooled, or when those from the Peace River and Caloosahatchee River results were pooled ( $t$-test: $t=-1.31, \mathrm{df}=13, \mathrm{p}=0.214$ ).

A significant hemoconcentration was observed in the blood of YOY sampled in the Peace River, when compared with individuals sampled in FLBLE and UE. The percent hematocrit was not significantly higher in the Peace River than in the Caloosahatchee River, and the Caloosahatchee River YOY did not have significantly higher percent hematocrit than that of the UE (ANOVA: $F_{3,38}=8.02, \mathrm{p}<0.001$; Fig. 3D).

\section{DISCUSSION}

This study is the first to document stress physiology parameters in the smalltooth sawfish Pristis pectinata by ontogeny, capture method, and habitat quality. When comparing all of the parameters investigated between $P$. pectinata and previously examined elasmobranchs, $P$. pectinata appear to have a similar or less pronounced stress response, suggesting physiological resiliency in the species. In particular, glucose and lactate were relatively low when compared to other elasmobranchs. Glucose in $P$. pectinata was most similar to demersal species such as the southern stingray Hypanus americana, which had a median glucose concentration of $1.7 \mathrm{mmol} \mathrm{l}^{-1}$ after trawling (Cain et al. 2004), and the Port Jackson shark Heterodontus portusjacksoni, which had average glucose concentrations between 1.61 and 2.28 mmol $\mathrm{l}^{-1}$, depending on the treat- ment and duration, before and after gillnet and longline capture simulations (Frick et al. 2010a). In contrast, in the 11 species of ram-ventilating sharks examined by Marshall et al. (2012), the lowest average glucose concentration was $\sim 5 \mathrm{mmol}^{-1}$, and in the gummy shark Mustelus antarcticus, glucose ranged from 3.98 to $6.14 \mathrm{mmol} \mathrm{l}^{-1}$ before and after gillnet and longline capture simulations (Frick et al. 2010a). While behavior was not directly recorded in the present study, sawfish are known to rest on the substrate and live a more sedentary lifestyle. During this study, $P$. pectinata were observed to rest on the substrate after capture, similar to $H$. portusjacksoni during simulated capture (Frick et al. 2010a), and as inferred from temperature depth recorder behavior data in longline captured $M$. antarcticus (Guida et al. 2016). This behavior could contribute to lower glucose concentrations, as observed in teleosts (Vijayan \& Moon 1994, Waring et al. 1996), by either stopping glucose levels from rising higher or allowing time for clearance.

Average concentrations of lactate, one of the most commonly used indicators of stress, in $P$. pectinata ranged from 0.9 to $3.5 \mathrm{mmol} \mathrm{l}^{-1}$ over ontogeny and different capture methods and were very low relative to those of other elasmobranchs studied to date (Fig. 4). For example, Marshall et al. (2012) examined blood lactate in 11 shark species captured by longline, and only 1 species, the oceanic whitetip shark Carcharhinus longimanus, displayed a mean lactate concentration less than $4 \mathrm{mmol}^{-1}$. Moyes et al. (2006) found that lactate was one of the best predictors of post-release mortality, with moribund blue

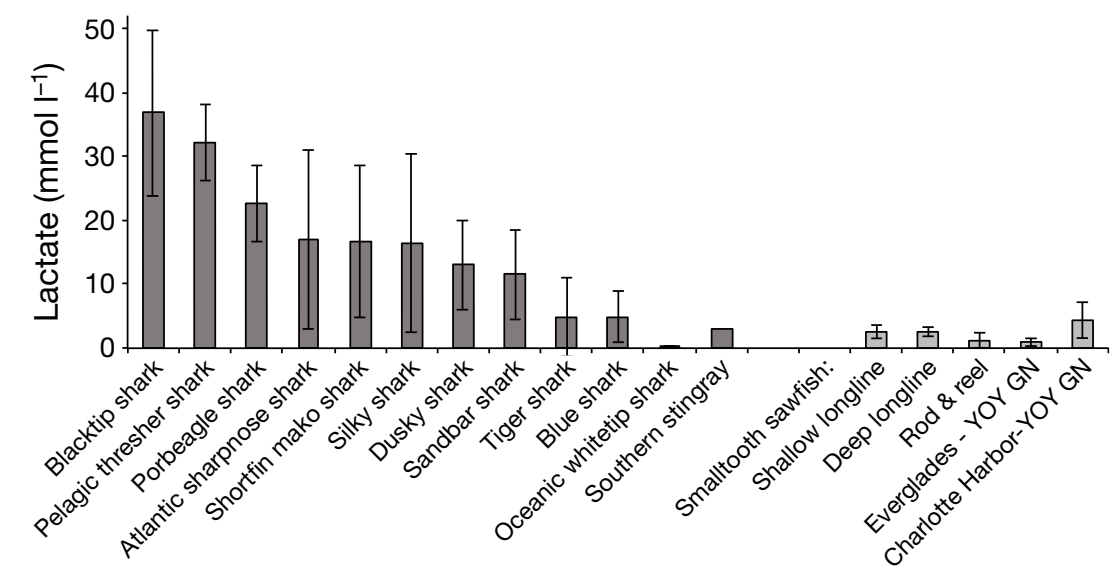

Fig. 4. Bar plot comparing smalltooth sawfish Pristis pectinata lactate concentrations $\left(\mathrm{mmol} \mathrm{l}^{-1}\right)$ measured in the present study to concentrations from 11 species of longline captured sharks (from Marshall et al. 2012) and trawl captured southern stingray Dasyatis americana (from Cain et al. 2004). Pristis pectinata are subdivided into shallow longline, deep longline, rod and reel, Everglades young of the year (YOY) gillnet (GN) capture, and Charlotte Harbor YOY GN 
shark Prionace glauca having blood lactate values around $20 \mathrm{mmol} \mathrm{l}^{-1}$. Hight et al. (2007) reported mortality occurred with lactate $\sim 16 \mathrm{mmol}^{-1}$ in P. glauca, $19 \mathrm{mmol} \mathrm{l}^{-1}$ in common thresher sharks Alopias vulpinus, and $20 \mathrm{mmol} \mathrm{l}^{-1}$ in shortfin mako sharks Isurus oxyrinchus; however, they also reported survival based on tag recaptures of I. oxyrhinchus with lactate values at tagging ranging from 10.3 to $14.7 \mathrm{mmol} \mathrm{l}^{-1}$ as well as for $1 \mathrm{~A}$. vulpinus with a lactate value at tagging of $23 \mathrm{mmol} \mathrm{l}^{-1}$. In Cain et al. (2004), bottomtrawled $H$. americana displayed a median lactate of $3.1 \mathrm{mmol} \mathrm{l}^{-1}$, similar to that of $P$. pectinata in the present study (see Fig. 4).

Lactate concentrations have been found to be significantly higher in gillnet captured bonnethead sharks Sphyrna tiburo, bull sharks C. leucas, lemon sharks Negaprion brevirostris, and M. antarcticus than those captured by longline (Frick et al. 2010a, Hyatt et al. 2012). While lactate concentrations in $P$. pectinata had the same trend, the average concentration was lower than that for all the aforementioned elasmobranchs (Frick et al. 2010a, Hyatt et al. 2012). Additionally, the handling time prior to obtaining the blood sample is likely to increase the stress response cascade. Although this handling time is greatest for longline captured adults, the lactate level was comparable, if not higher, in gillnet captured P. pectinata which experienced less handling time prior to sampling. This reinforces the US research permit requirement for constant monitoring of all gillnets targeting $P$. pectinata.

Plasma potassium concentration of gillnet captured $P$. pectinata was the only parameter examined in the present study that was neither comparable to nor indicative of lower stress than that of other elasmobranchs (Frick et al. 2010a, Marshall et al. 2012). Despite relatively elevated concentrations of potassium, tag-recapture and tracking data suggested that no $P$. pectinata captured during this study died post-release. This may indicate that $P$. pectinata has a higher threshold for the damaging effects of hyperkalemia, that this species has the ability to recover from acutely elevated potassium, as has been observed in spiny dogfish Squalus acanthias (Mandelman \& Farrington 2007), or that potassium may not be a reliable indicator of physiological stress in this species. Additionally, despite following identical protocols to other elasmobranch blood collections, P. pectinata blood samples all showed high levels of hemolysis, which may have resulted in greater concentrations of plasma potassium, similar to what was found in $S$. acanthias by Martini (1974). This could limit the use of this parameter for comparative purposes.

\section{Ontogeny}

Of the 7 stress physiology parameters that were investigated, 6 were found to vary significantly over ontogeny. However, when capture method was held constant to elucidate stage-specific differences, only bicarbonate, $\mathrm{pH}$, and hematocrit varied significantly, suggesting that our results investigating physiological stress as functions of ontogeny and capture method were confounded.

Both YOY and juvenile $P$. pectinata had significantly higher concentrations of bicarbonate than adults. Because bicarbonate can act as a buffer for lactate increases, it is possible that this physiological functioning is more efficient, or only occurs in the adult stage, since YOY had the highest lactate as well as the highest bicarbonate concentrations. However, it is also likely that gillnet captured $P$. pectinata were removed from the net and sampled too quickly to observe a decline in bicarbonate. Significantly lower blood $\mathrm{pH}$ and a much larger range in $\mathrm{pH}$ were observed in YOY and gillnet captured juveniles than in adults. This is likely driven by life stage, since this was observed when capture method was held constant, and is likely a result of higher lactate, higher $\mathrm{pCO}_{2}$, and higher bicarbonate concentrations, all of which can contribute to blood acidosis. Dissimilar to the results here, when investigating the $\mathrm{pH}$ response over total length in 5 shark species, Gallagher et al. (2014) did not find a significant interaction; however, that study had a smaller sample size over a smaller size range. A significant hemoconcentration of the blood was observed in the present study in YOY P. pectinata when compared with juveniles and adults, and this significant trend was still observed when only gillnet captured YOY and juveniles were analyzed. The significant hemoconcentration observed in YOY $P$. pectinata was likely because of their higher range of lactate concentrations. Bicarbonate, $\mathrm{pH}$, and hematocrit are directly linked to metabolic and respiratory stress, which is typically first indicated by $\mathrm{pCO}_{2}$ and lactate. Overall, when investigating all of the stress physiology parameters, there was likely little change in the response as a result of age, but rather from capture method. Similarly, Mandelman \& Skomal (2009) compared stress parameters over fork length of 4 shark species, and did not find any differences as a result of length; however, they noted their low intraspecific variability in size and variation in capture duration as potential reasons for not detecting differences over ontogeny. 


\section{Capture method}

Gillnet captured $P$. pectinata had significantly higher glucose, $\mathrm{pCO}_{2}$, bicarbonate, potassium, and hematocrit compared to longline captured individuals; however, lactate and blood $\mathrm{pH}$ were not significantly different between these capture methods. Gillnet capture may induce a larger stress response relative to that of a longline because of the limitation in mobility, and potential impediment of ventilation (Manire et al. 2001), whereas longline capture allows a fish to continue swimming or lie on the bottom with unrestricted ventilation (Manire et al. 2001, Hyatt et al. 2012, Guida et al. 2016). However, field observations suggest that juvenile $P$. pectinata react by settling onto the substrate with the rostrum entangled in the mesh. Dissimilar to the results of the present study, Hyatt et al. (2012) found that lactate concentrations were significantly higher and $\mathrm{pH}$ was significantly lower in gillnet captured S. tiburo, C. leucas, and $N$. brevirostris, although they found no significant difference in blood $\mathrm{pCO}_{2}$ and bicarbonate. In elasmobranchs, because bicarbonate concentrations can be directly related to lactate concentrations (Holeton \& Heisler 1983), it would be expected that all of the capture methods in the present study should have comparable depletions of bicarbonate; however, bicarbonate was only found to be depleted in shallow and deep longline captured $P$. pectinata. The differences in blood bicarbonate across capture methods may be a result of the greater time lag between capture and sampling for longline, during which bicarbonate buffering may occur. Mean potassium in longline captured $P$. pectinata was similar to that observed in sharks (Frick et al. 2010a, Marshall et al. 2012); however, the significantly higher potassium concentrations observed in gillnet captured $P$. pectinata were likely related to greater instances of hemolysis in the blood of YOY. Similarly, the significant hemoconcentration observed in gillnet captured $P$. pectinata when compared with longline captured individuals could also be related to the predominance of YOY captured by gillnet. This is further supported by the significant hemoconcentration found in gillnet captured YOY compared to juveniles.

The only parameter that indicated any significant difference in the stress response between shallow and deep longline was blood glucose, which indicated greater stress in deep longline caught individuals. This may be because of the time required to pull the $P$. pectinata $40-80 \mathrm{~m}$ from the substrate to the surface.

While not statistically analyzed, lactate, bicarbonate, $\mathrm{pH}$, potassium, and hematocrit indicated less stress with rod and reel and dip net captures. Although blood samples were collected as soon as the fish was restrained, some handling may have induced greater stress in longline and gillnet captured P. pectinata, because rod and reel and dip net captured individuals were sampled within 1 min of gear contact. The rod and reel gear used in this study was heavier than that commonly used by recreational fishers, reducing the fight time to less than $1 \mathrm{~min}$. Baseline or near baseline levels of lactate in some species of sharks have been reported between 0 and $1 \mathrm{mmol}^{-1}$ (Cliff \& Thurman 1984, Spargo 2001, Skomal 2006, Brooks et al. 2012); therefore, these similar concentrations in rod and reel and dip net captured $P$. pectinata may represent near-baseline levels of lactate for this species.

Overall, the results indicate that gillnet capture may induce both greater relative metabolic and respiratory stress in this species, although it is important to acknowledge that ontogeny may be confounding these results, particularly regarding potassium and hematocrit. Regardless, comparison to previous work on other elasmobranchs suggests that stress was relatively low for $P$. pectinata across all capture methods.

\section{Habitat quality}

Of the 7 stress physiology parameters assessed, lactate, bicarbonate, $\mathrm{pH}$, and hematocrit significantly differed in YOY and juveniles between nurseries. These parameters suggest that there may be chronic metabolic stress occurring in the more anthropogenically altered nurseries, the Peace and Caloosahatchee rivers, than in the relatively pristine nurseries in the TTI/ENP Unit. Changes in these 4 stress physiology parameters are likely the result of habitat degradation in the form of less refuge from human and predator interactions, and poorer abiotic conditions, which could elicit behavioral and physiological compensations (Skomal \& Mandelman 2012), potentially leading to increased metabolic activity and, subsequently, higher lactate and hematocrit, as well as lower bicarbonate and $\mathrm{pH}$. Chronic stress related to habitat loss can have negative population-level effects through reproductive, growth, and immune system impairments (Sapolsky 1992, Wingfield \& Romero 2001). These observations are especially relevant from conservation and management perspectives in light of recent evidence that $P$. pectinata exhibit interannual site fidelity to the Peace and Caloosahatchee rivers (Feldheim et al. 2017). 


\section{Conclusions}

Lactate is a commonly used indicator of stress and capture survival in elasmobranchs, and $P$. pectinata blood lactate concentration was among the lowest studied in elasmobranchs to date. Lactate was similar among capture methods. The lower concentrations of lactate observed in P. pectinata are likely in part because this species is a benthic, sedentary fish, and thus less sensitive physiologically to capture than most other previously examined elasmobranchs.

Our results indicate there may be chronic metabolic stress associated with the more anthropogenically influenced nurseries than in the relatively pristine nurseries. P. pectinata in the Peace and Caloosahatchee rivers had significantly higher lactate and hematocrit, and decreased $\mathrm{pH}$ and bicarbonate in comparison to individuals in the TTI/ENP Unit.

Future directions of $P$. pectinata stress physiology research should focus on sampling more individuals using the rod and reel capture method. This is likely the most common capture method that $P$. pectinata are exposed to today, and understanding how $P$. pectinata respond physiologically to this capture method is of great importance for understanding how they may recover once released. Additionally, similar to studies by Frick et al. $(2010 a, b)$ in which stress responses were compared between simulated longline, gillnet, and trawl captured H. portusjacksoni and $M$. antarcticus, $P$. pectinata that are captured via shrimp trawl should also be sampled to determine if these fish have the potential to survive once released, based on comparing their biochemical parameters to those measured in other moribund elasmobranchs. Overall, the results of our study indicate that $P$. pectinata is a species resilient to capture using the methods studied here. Ongoing tagging and telemetry studies of animals captured in these surveys indicate that post-release survival is very high. These results suggest that if harvest restrictions are enforced and suitable habitats are protected, the recovery outlook is positive for this imperiled species.

Acknowledgements. Thank you to all of the employees and volunteers who helped sample on the Florida State University (FSU), National Marine Fisheries Service (NMFS), and Florida Fish and Wildlife Conservation Commission (FWC) smalltooth sawfish surveys. Funding to support the FSU surveys was from the National Oceanic and Atmospheric Administration's (NOAA) Office of Protected Resources through the Northern Gulf Institute and the US Department of Defense. Special thanks to A. Brame at NOAA SERO for providing funding for the NMFS survey. Funding to support the FWC surveys was from the US Department of Commerce (DOC), NOAA's National Marine Fisheries Service through
Section 6 (Cooperation with the States) of the US Endangered Species Act under the following grant award to the FWC from the DOC, NOAA-NA13NMF4720047. All samples were collected under FSU Animal Care and Use Committee Protocol 1411. Thank you to John Mandelman, the New England Aquarium, and University of Massachusetts Boston for assistance with quantifying plasma potassium. Thank you to all of the FSU Grubbs Lab, and University of North Florida Gelsleichter Lab members who participated in these surveys, in particular Johanna Imhoff and Chelsea Shields for collecting and processing blood samples in the senior author's absence. Thank you to the Gumbo Limbo Nature Center for their Gordon Gilbert Scholarship awarded to the senior author. This research was conducted under NOAA survey permit SEFSC-NMFS-17787, FSU survey permits SAL-14-1345, SAL-15-1345, and SAL-16-1345, and FWC survey permit SEFSC-NMFS-15802. Research in Everglades National Park was conducted under permits ENP-2014-SCI-0009, ENP2015-SCI-0002, and ENP-2016-SCI-0016. Research in the Florida Keys National Marine Sanctuary was conducted under permits FKNMS-LOA-2014-016, FKNMS-LOA-2015040, and FKNMS-LOA-2016-004. This work was presented as part of the symposium 'Biology and Ecology of Sawfishes' at the 2016 annual meeting of the American Elasmobranch Society, which was supported by funding from the Save Our Seas Foundation, Disney Conservation Fund, and the American Elasmobranch Society.

\section{LITERATURE CITED}

Adams PR, Galvan M (1986) Voltage-dependent currents of vertebrate neurons and their role in membrane excitability. Adv Neurol 44:137-170

Anderson WG (2012) The endocrinology of $1 \alpha$-hydroxycorticosterone in elasmobranch fish: a review. Comp Biochem Physiol A 162:73-80

Arlinghaus R, Klefoth T, Cooke SJ, Gingerich AJ, Suski CD (2009) A combined laboratory and field study to understand physiological and behavioral disturbance and recovery from catch-and-release recreational angling in northern pike (Esox lucius). Fish Res 97:223-233

Barnes T (2005) Caloosahatchee Estuary conceptual ecological model. Wetlands 25:884-897

*Barton BA, Iwama G (1991) Physiological changes in fish from stress in aquaculture with emphasis on the response and effects of corticosteroids. Annu Rev Fish Dis 1:3-26

* Black EC (1958) Hyperactivity as a lethal factor in fish. J Fish Res Board Can 15:573-586

* Brooks EJ, Mandelman JW, Sloman KA, Liss S and others (2012) The physiological response of the Caribbean reef shark (Carcharhinus perezi) to longline capture. Comp Biochem Physiol A Mol Integr Physiol 162:94-100

* Cain DK, Harms CA, Segars A (2004) Plasma biochemistry reference values of wild-caught southern stingrays (Dasyatis americana). J Zoo Wildl Med 35:471-476

Carlson JK, Baremore IE (2003) The Directed Shark Gillnet Fishery: Catch and Bycatch, 2003. US Department of Commerce, NOAA National Marine Fisheries Service, Southeast Fisheries Science Center, Panama City, FL, SFD Contribution PCB-03-07

Carlson J, Scott-Denton E (2011) Estimated incidental take of smalltooth sawfish (Pristis pectinata) and an assessment of observer coverage required in the South Atlantic and Gulf of Mexico shrimp trawl fishery. US Department 
of Commerce, NOAA National Marine Fisheries Service, Southeast Fisheries Science Center, Panama City, FL, SFD Contribution PCB-11-08

Carlson J, Wiley T, Smith K (2013) Pristis pectinata. The IUCN Red List of Threatened Species. www.iucnredlist. org/ (accessed 01 May 2016)

Carlson JK, Gulak SJB, Simpfendorfer CA, Grubbs RD, Romine JG, Burgess GH (2014) Movement patterns and habitat use of smalltooth sawfish, Pristis pectinata, determined using pop-up satellite archival tags. Aquat Conserv 24:104-117

Cliff G, Thurman G (1984) Pathological and physiological effects of stress during capture and transport in the juvenile dusky shark, Carcharhinus obscurus. Comp Biochem Physiol A Physiol 78:167-173

Cooke SJ, Suski CD, Danylchuk SE, Danylchuk AJ and others (2008) Effects of different capture techniques on the physiological condition of bonefish Albula vulpes evaluated using field diagnostic tools. J Fish Biol 73: 1351-1375

Creel S, Creel NM, Monfort SL (1997) Radiocollaring and stress hormones in African wild dogs. Conserv Biol 11: 544-548

Dulvy NK, Fowler SL, Musick JA, Cavanagh RD and others (2014) Extinction risk and conservation of the world's sharks and rays. eLife 3:e00590

* Dulvy NK, Davidson LNK, Kyne PM, Simpfendorfer CA, Harrison LR, Carlson JK, Fordham SV (2016) Ghosts of the coast: global extinction risk and conservation of sawfishes. Aquat Conserv 26:134-153

Enzenauer MP, Deacy BM, Carlson JK (2016) Characterization of the shark bottom longline fishery, 2015. NOAA Tech Memo NMFS-SEFSC-689

Faria VV, McDavitt MT, Charvet P, Wiley TR, Simpfendorfer CA, Naylor GJP (2013) Species delineation and global population structure of Critically Endangered sawfishes (Pristidae). Zool J Linn Soc 167:136-164

Feldheim KA, Fields AT, Chapman DD, Scharer RM, Poulakis GR (2017) Insights into reproduction and behavior of the smalltooth sawfish Pristis pectinata. Endang Species Res 34:463-471

Ferguson RA, Tufts BL (1992) Physiological effects of brief air exposure in exhaustively exercised rainbow trout (Oncorhynchus mykiss): implications for 'catch and release' fisheries. Can J Fish Aquat Sci 49:1157-1162

Frick LH, Reina RD, Walker TI (2010a) Stress related physiological changes and post-release survival of Port Jackson sharks (Heterodontus portusjacksoni) and gummy sharks (Mustelus antarcticus) following gill-net and longline capture in captivity. J Exp Mar Biol Ecol 385:29-37

Frick LH, Walker TI, Reina RD (2010b) Trawl capture of Port Jackson sharks, Heterodontus portusjacksoni, and gummy sharks, Mustelus antarcticus, in a controlled setting: effects of tow duration, air exposure and crowding. Fish Res 106:344-350

FWC (Florida Fish and Wildlife Conservation Commission) (1999) Protected species: sawfishes, basking shark, white shark, sand tiger shark, bigeye sand tiger shark, manta ray and spotted eagle ray; prohibition of harvest, landing, or sale. Ch 68B-44.008. Fla Admin Code Rule

Gallagher AJ, Frick LH, Bushnell PG, Brill RW, Mandelman JW (2010) Blood gas, oxygen saturation, $\mathrm{pH}$, and lactate values in elasmobranch blood measured with a commercially available portable clinical analyzer and standard laboratory instruments. J Aquat Anim Health 22:229-234
Gallagher AJ, Serafy JE, Cooke SJ, Hammerschlag N (2014) Physiological stress response, reflex impairment, and survival of five sympatric shark species following experimental capture and release. Mar Ecol Prog Ser 496:207-218

* Guida L, Walker TI, Reina RD (2016) Temperature insensitivity and behavioural reduction of the physiological stress response to longline capture by the gummy shark, Mustelus antarcticus. PLOS ONE 11:e0148829

* Harrenstien LA, Tornquist ST, Miller-Morgan TJ, Fodness BG, Clifford KE (2005) Evaluation of a point-of-care blood analyzer and determination of reference ranges for blood parameters in rockfish. J Am Vet Med Assoc 226:255-265

*Hight BV, Holts D, Graham JB, Kennedy BP and others (2007) Plasma catecholamine levels as indicators of the post-release survivorship of juvenile pelagic sharks caught on experimental drift longlines in the Southern California Bight. Mar Freshw Res 58:145-151

*Hoffmayer ER, Parsons GR (2001) The physiological response to capture and handling stress in the Atlantic sharpnose shark, Rhizoprionodon terraenovae. Fish Physiol Biochem 25:277-285

Holeton GF, Heisler N (1983) Contribution of net ion transfer mechanisms to acid-base regulation after exhausting activity in the larger spotted dogfish (Scyliorhinus stellaris). J Exp Biol 103:31-46

Hollensead LD, Grubbs RD, Carlson JK, Bethea DM (2016) Analysis of fine-scale daily movement patterns of juvenile Pristis pectinata within a nursery habitat. Aquat Conserv 26:492-505

*Hyatt MW, Anderson PA, O'Donnell PM, Berzins IK (2012) Assessment of acid-base derangements among bonnethead (Sphyrna tiburo), bull (Carcharhinus leucas), and lemon (Negaprion brevirostris) sharks form gillnet and longline capture and handling methods. Comp Biochem Physiol A 162:113-120

*Lindinger MI, Kowalchuk JM, Heigenhauser GJF (2005) Applying physicochemical principles to skeletal muscle acid-base status. Am J Physiol Regul Integr Comp Physiol 289:R891-R894

* Mandelman JW, Farrington MA (2007) The physiological status and mortality associated with otter trawl capture, transport, and captivity of an exploited elasmobranch Squalus acanthias. ICES J Mar Sci 64:122-130

*Mandelman JW, Skomal GB (2009) Differential sensitivity to capture stress assessed by blood acid-base status in five carcharhinid sharks. J Comp Physiol B 179:267-277

* Manire C, Hueter R, Hull E, Spieler R (2001) Serological changes associated with gill-net capture and restraint in three species of sharks. Trans Am Fish Soc 130:1038-1048

*Marshall H, Field L, Afiadata A, Sepulveda C, Skomal G, Bernal D (2012) Hematological indicators of stress in longline-captured sharks. Comp Biochem Physiol A 162: $121-129$

Martini FH (1974) Effects of capture and fasting confinement on an elasmobranch, Squalus acanthias. PhD dissertation, Cornell University, Ithaca, NY

Moyes CD, Fragoso N, Musyl M, Brill RW (2006) Predicting post-release survival in large pelagic fish. Trans Am Fish Soc 135:1389-1397

Murdaugh HV Jr, Robin ED, Theodore J, Drewry W (1965) Studies of lactate metabolism in Squalus acanthias. Bull Mt Des Is Biol Lab 5:30-31

NMFS (United States National Marine Fisheries Service) (2003) Endangered and threatened species; final endangered status for a distinct population segment of small- 
tooth sawfish (Pristis pectinata) in the United States. Fed Regist 68:15674-15680

NMFS (United States National Marine Fisheries Service) (2009) Recovery plan for smalltooth sawfish (Pristis pectinata). Prepared by the Smalltooth Sawfish Recovery Team for the National Marine Fisheries Service, Silver Spring, MD

Norton SL, Wiley TR, Carlson JK, Frick AL, Poulakis GR, Simpfendorfer CA (2012) Designating critical habitat for juvenile endangered smalltooth sawfish in the United States. Mar Coast Fish 4:473-480

Piiper J, Baumgarten D (1969) Blood lactate and acid-base balance in the elasmobranch Scyliorhinus stellaris after exhausting activity. Pubbl Staz Zool Napoli 37:84-94

Piiper J, Meyer M, Drees F (1972) Hydrogen ion balance in the elasmobranch, Scyliorhinus stellaris, after exhausting activity. Respir Physiol 16:290-303

Poulakis GR, Seitz JC (2004) Recent occurrence of the smalltooth sawfish, Pristis pectinata (Elasmobranchiomorphi: Pristidae), in Florida Bay and the Florida Keys, with comments on sawfish ecology. Fla Sci 67:27-35

* Poulakis GR, Stevens PW, Timmers AA, Wiley TR, Simpfendorfer CA (2011) Abiotic affinities and spatiotemporal distribution of the endangered smalltooth sawfish, Pristis pectinata, in a south-western Florida nursery. Mar Freshw Res 62:1165-1177

R Development Core Team (2014) R: a language and environment for statistical computing. R Foundation for Statistical Computing. www.R-project.org/ (accessed 1 Sep 2014)

Rasmussen RA, Rasmussen LE (1967) Some observations on the protein and enzyme levels and fractions in normal and stressed elasmobranchs. Trans N Y Acad Sci 29: 397-413

Ricklefs RE, Wikelski M (2002) The physiology/life-history nexus. Trends Ecol Evol 17:462-468

Robergs RA, Ghiasvand F, Parker D (2004) Biochemistry of exercise-induced metabolic acidosis. Am J Physiol Regul Integr Comp Physiol 287:R502-R516

Sapolsky RM (1992) Stress, the aging brain and the mechanisms of neuron death. MIT Press, Cambridge, MA

Schmidt-Nielsen K (1997) Animal physiology: adaptation and the environment. Cambridge University Press, Cambridge

Seitz JC, Poulakis GR (2002) Recent occurrence of sawfishes (Elasmobranchiomorphi: Pristidae) along the southwest coast of Florida (USA). Fla Sci 65:256-266

Seitz JC, Poulakis GR (2006) Anthropogenic effects on the smalltooth sawfish (Pristis pectinata) in the United States. Mar Pollut Bull 52:1533-1540

Simpfendorfer CA (2000) Predicting population recovery rates for endangered western Atlantic sawfishes using demographic analysis. Environ Biol Fishes 58:371-377

Simpfendorfer CA (2005) Threatened fishes of the world: Pristis pectinata Latham, 1794 (Pristidae). Environ Biol Fishes 73:20

Simpfendorfer CA, Poulakis GR, O'Donnell PM, Wiley TR (2008) Growth rates of juvenile smalltooth sawfish Pristis pectinata Latham in the western Atlantic. J Fish Biol 72: 711-723

Simpfendorfer CA, Wiley TR, Yeiser BG (2010) Improving conservation planning for an endangered sawfish

Editorial responsibility: Brendan Godley,

University of Exeter, Cornwall Campus, UK using data from acoustic telemetry. Biol Conserv 143: 1460-1469

Skomal GB (2006) The physiological effects of capture stress on post-release survivorship of sharks, tunas, and marlin. PhD dissertation, Boston University, Boston, MA

Skomal GB (2007) Evaluating the physiological and physical consequences of capture on post-release survivorship in large pelagic fishes. Fish Manag Ecol 14:81-89

Skomal GB, Bernal D (2010) Physiological responses to stress in sharks. In: Carrier JC, Musick JA, Heithaus MR (eds) Sharks and their relatives II: biodiversity, adaptive physiology, and conservation. CRC Marine Biology Series, Boca Raton, FL, p 459-490

Skomal GB, Mandelman JW (2012) The physiological response to anthropogenic stressors in marine elasmobranch fishes: a review with a focus on the secondary response. Comp Biochem Physiol A 162:146-155

Spargo A (2001) The physiological effects of catch and release angling on the post release survivorship of juvenile sandbar sharks (Carcharhinus plumbeus). MSc thesis, University of Rhode Island, Kingston, RI

VVijayan MM, Moon TW (1994) The stress response and plasma disappearance of corticosteroid and glucose in a marine teleost, the sea raven. Can J Zool 72:379-386

*Waring CP, Stagg RM, Poxton MG (1996) Physiological responses to handling in the turbot. J Fish Biol 48:161-173

*Wasser SK, Bervis K, King G, Hanson E (1997) Non-invasive physiological measures of disturbance in the northern spotted owl. Conserv Biol 11:1019-1022

Waters JD, Coelho R, Fernandez-Carvalho J, Timmers AA and others (2014) Use of encounter data to model spatiotemporal distribution patterns of endangered smalltooth sawfish, Pristis pectinata, in the western Atlantic. Aquat Conserv 24:760-776

Wells RMG, McIntyre RH, Morgan AK, Davie PS (1986) Physiological stress responses in big gamefish after capture: observations on plasma chemistry and blood factors. Comp Biochem Physiol A 84:565-571

*Wikelski M, Cooke SJ (2006) Conservation physiology. Trends Ecol Evol 21:38-46

Wiley TR, Simpfendorfer CA (2007) The ecology of elasmobranchs occurring in the Everglades National Park, Florida: implications for conservation and management. Bull Mar Sci 80:171-189

Wiley TR, Simpfendorfer CA (2010) Using public encounter data to direct recovery efforts for the endangered smalltooth sawfish Pristis pectinata. Endang Species Res 12: 179-191

Wingfield JC, Romero LM (2001) Andrenocortical responses to stress and their modulation in free-living ertebrates. In: McEwen, BS, Goodman HM (eds) Handbook of physiology, section 7: the endocrine system, Vol. IV: coping with the environment: neural and endocrine mechanisms. Oxford University Press, New York, NY, p 211-234

*Wueringer B, Squire L, Collin S (2009) The biology of extinct and extant sawfish (Batoidea: Sclerorhynchidae and Pristidae). Rev Fish Biol Fish 19:445-464

*Young JL, Bornik Z, Marcotte M, Charlie K, Wagner GN, Hinch SG, Cooke SJ (2006) Integrating physiology and life history to improve fisheries management and conservation. Fish Fish 7:262-283

Submitted: October 4, 2017; Accepted: March 31, 2018

Proofs received from author(s): June 13, 2018 